Religare, ISSN: 19826605, v.16, n.1, agosto de 2019, p.282-305.

\title{
A Teologia da Prosperidade e as representações acerca do Diabo no Neopentecostalismo da Igreja Universal do Reino de Deus: uma conexão necessária
}

\author{
Prosperity Theology and representations of the devil in \\ Neopentecostalism of the Universal Church of the Kingdom of \\ God: a necessary connection
}

Marcello Felipe Duarte ${ }^{1}$

\section{Resumo}

Esse artigo tem o objetivo de realizar um estudo sobre a relação existente entre a Teologia da Prosperidade baseada, principalmente, na perspectiva teológica denominada economia sacrificial, e as práticas e representações acerca do diabo produzidas pela Igreja Universal do Reino de Deus. Tal relação é fundamental para explicar a construção da identidade neopentecostal iurdiana por meio da demonização das religiões de matriz afro-brasileira. A guerra espiritual contra as forças do mal promovida pela IURD se traduz em uma clara dicotomia entre o Reino de Deus, no qual se pode usufruir de suas bênçãos, e o Reino das Trevas, caracterizado pela ação do diabo na vida das pessoas que, por estarem distantes da vontade divina, sofrem toda sorte de maldições, como doenças e a miséria.

Palavras-chave: Teologia da Prosperidade; economia sacrificial, representações acerca do diabo, IURD, Neopentecostalismo.

\begin{abstract}
This article aims to accomplish a study on the relationship between Theology of Prosperity based mainly on the theological perspective referred to sacrificial economy and the practices and representations about the devil produced by the Universal Church of the Kingdom of God (UCKG). This such relationship is fundamental to explain the construction of identity NeoPentecostal through the demonization of Afro-Brazilian religions. The spiritual warfare against the forces of evil promoted by the UCKG translates into a clear dichotomy between God's Kingdom in which you can enjoy your blessings and the Kingdom of Darkness, characterized by the action of the devil in the lives of people who for
\end{abstract}

\footnotetext{
${ }^{1}$ Mestre e Doutor em História pela UERJ.
} 
Religare, ISSN: 19826605, v.16, n.1, agosto de 2019, p.282-305.

being distant from the divine will suffer all sorts of curses, such as disease and misery.

Keywords: Theology of Prosperity, sacrificial economy, representations about the devil, UCKG, neopentecostalism.

Qualquer manifestação religiosa mais recente tende a buscar o seu lugar no campo religioso a partir de uma postura de afirmação de sua própria legitimidade. Essa demarcação de posição, não raro, concretiza-se a partir do movimento de deslocamento das outras experiências religiosas para o universo da magia ou da feitiçaria. A Igreja Universal do Reino de Deus (IURD), fundada em 1977, construiu sua afirmação espiritual-institucional seguindo essa tendência:

Uma vez que a religião, e em geral todo sistema simbólico está predisposta a cumprir uma função de associação e de dissociação, ou melhor, de distinção, um sistema de práticas e crenças está fadado a surgir como magia ou como feitiçaria, no sentido de religião inferior, todas as vezes que ocupar uma posição dominada na estrutura de relações de força simbólica, ou seja, no sistema das relações entre o sistema de práticas e de crenças próprias a uma formação social determinada. Desta maneira, costuma-se designar em geral como magia tanto uma religião inferior e antiga, logo primitiva, quanto uma religião inferior e contemporânea, logo profana (aqui equivalente a vulgar) e profanadora. Assim a aparição de uma ideologia religiosa tem por feito relegar os antigos mitos ao estado de magia ou de feitiçaria (BOURDIEU, 1998, p. 43-44).

De acordo com Cascudo, autor de um dicionário do folclore brasileiro, tanto os africanos como os índios não possuíam em seus respectivos universos religiosos um ser espiritual que personificasse a ideia absoluta de mal como o diabo no cristianismo (CASCUDO, s.d., p. 353). Ocorreu, inicialmente, uma transposição europeia da representação do diabo para a América Portuguesa, durante o período colonial, e a partir de então sucessivas ressignificações e (re) apropriações em relação às entidades de matrizes indígena e africana. 
Religare, ISSN: 19826605, v.16, n.1, agosto de 2019, p.282-305.

A desconstrução da legitimidade das expressões religiosas afrobrasileiras e do Espiritismo ocorreu por meio da demonização de suas práticas e ritos religiosos reforçando seu caráter mágico, utilizando-se, para isso, da figura do diabo que teria uma excepcional funcionalidade para marcar a construção identitária da comunidade religiosa iurdiana.

Com o triunfo do monoteísmo tornava-se necessário explicar a presença do mal no mundo, uma vez que Deus era bondoso, reto e perfeito. Assim, “o diabo ajudou a sustentar a ideia de uma divindade absolutamente perfeita" (THOMAS, 1980, p. 477) sendo que a imperfeição física do demônio não só evidenciava sua imperfeição externa, mas, sobretudo, servia como contraponto à perfeição divina.

Essa dicotomia pode ser observada também nas suas diferentes origens: "O Anticristo era a contrapartida maligna de Cristo. Este era todo bondade e luz - O Salvador; o outro, todo maldade e escuridão - o Destruidor. Um nascido de uma virgem; o outro de uma prostituta" (NOGUEIRA, 2000, p. 66).

É preciso ressaltar também que tanto a permanência de um imaginário coletivo preconceituoso e negativo dessas religiões afro-brasileiras e do Espiritismo (MARIANO, 1999, p.127), quanto à herança que a IURD recebeu do próprio pentecostalismo tradicional contribuíram para reforçar essa tendência para a demonização.

Existe uma interessante ambivalência no processo de negação/demonização das religiões de matriz africana e do Espiritismo, isto porque essa desqualificação vem acompanhada de certas assimilações e práticas rituais de seus adversários. Tendo em vista essa diversidade de freqüentadores, a IURD tem lançado mão de uma estratégia, muito criticada pelas igrejas evangélicas tradicionais, nada convencional. Trata-se dos pontos de contatos, como sal grosso, água e rosa ungidas, fitas e pulseiras, para que as pessoas 
Religare, ISSN: 19826605, v.16, n.1, agosto de 2019, p.282-305.

imaturas na fé possam acessar o sagrado com maior facilidade, sobretudo, em razão da abstração inerente ao Cristianismo:

[...] nem todas as pessoas necessitam de "pontos de contato" para despertarem fé suficiente, mas a maioria precisa, razão pela qual realizamos nas reuniões as correntes e distribuímos gratuitamente coisas ligadas à Palavra de Deus direta ou indiretamente, literal ou simbolicamente, para trazer às pessoas uma confiança, pelo menos um fio de esperança, de fé, e assim levá-las a serem abençoadas. ${ }^{2}$

A IURD, ao mesmo tempo que demoniza, também incorpora elementos das religiões rivais, caracterizando-se como uma igreja religiofágica:

[...] mais que o transitar das entidades, o que de fato transitou e adquiriu uma nova fórmula foi o próprio transe. Pois somente quando a Igreja Universal admitiu o transe, recriando-o de forma específica, cravando-o no centro do seu ritual mais elaborado, é que as entidades puderam irromper no seu universo religioso [...]. A guerra santa travada consegue, dessa forma, conjugar um sincretismo invertido com a idéia de pluralismo religioso. E, como conseqüência, a Igreja Universal combate aquilo que, em parte, ajudou a criar (ALMEIDA, 1996, p. 62).

O bispo Macedo considera todos os orixás, pretos velhos e êres, como demônios e a IURD como instrumento de Deus, munida das armas espirituais necessárias para combatê-los. Nas sessões de descarrego é comum ver os demônios caindo de joelho e rolando no chão sob comando dos pastores e bispos (MACEDO, 1997, p. 128).

Dentre os orixás, Exu é a entidade religiosa que mais se amolda a essa associação com os demônios cristãos. Exu tem a incumbência de transportar as oferendas dos homens ao mundo dos deuses (Orum) e de transmitir as mensagens dos orixás ao mundo dos homens (Aiê). Portanto, é uma entidade que serve de ponte entre os dois mundos. Em razão disso, sem a sua existência e intermediação nada funciona.

\footnotetext{
2 Estatuto e regimento interno da Igreja Universal do Reino de Deus. Rio de Janeiro: Universal, 1993. p. 66-67.
} 
Religare, ISSN: 19826605, v.16, n.1, agosto de 2019, p.282-305.

É por meio dos sacrifícios que os homens reafirmam sua lealdade aos orixás ensejando o canal de comunicação necessário. Toda vez que um orixá é interpelado mediante uma oferenda, Exu também o é uma vez que sem a sua ação, seu trabalho de transportador, o elo entre o homem e os deuses não seria possível:

Como mensageiro dos deuses, Exu tudo sabe; não há segredos para ele, tudo ele ouve e tudo ele transmite. E pode quase tudo, pois conhece todas as receitas, todas as fórmulas, todas as magias. Exu trabalha para todos, não faz distinção entre aqueles a quem deve prestar serviço por imposição de seu cargo, o que inclui todas as divindades, mais os antepassados e os humanos. Exu não pode ter preferência por esse ou aquele. Mas talvez o que o distingue de todos os outros deuses é seu caráter de transformador: Exu é aquele que tem o poder de quebrar a tradição, pôr as regras em questão, romper a norma e promover a mudança. Não é, pois, de se estranhar que seja temido e considerado perigoso, posto que se trata daquele que é o próprio princípio do movimento, que tudo transforma, que não respeita limites. Assim, tudo o que contraria as normas sociais que regulam o cotidiano passa a ser atributo seu (PRANDI, 2005).

A figura de Exu se associa às ideias de intriga e malícia. Ele é capaz de colocar tudo de ponta-cabeça. Sua ação é marcada pela ambivalência, pois do mesmo modo que é capaz de separar amigos íntimos e provocar a ruína de qualquer pessoa, também pode enriquecer até mesmo um mendigo (PRANDI, 2001).

Considerado como uma entidade "fálica", "habitante das encruzilhadas" e "representante das potências contrárias ao homem" sua ação é temida por todos até mesmo pelos seus seguidores (CASCUDO, s.d., p. 379-380). Não é por acaso que sua imagem se encaixe perfeitamente à representação do diabo e que seja uma das entidades mais presentes e recorrentes nos exorcismos realizados na IURD.

A IURD trabalha por meio de campanhas e correntes, que são reuniões específicas para a solução de terminado problema. Uma das mais famosas é a 
Religare, ISSN: 19826605, v.16, n.1, agosto de 2019, p.282-305.

corrente de Libertação destinada às pessoas que estão sofrendo a ação direta do diabo em suas vidas. Os sintomas da ação das forças demoníacas são: desejo de suicídio, contato anterior com alguma entidade, ouvir vozes, medo, insônia e dores de cabeça persistentes (MACEDO, 1997, p. 73-80).

É razoável pensar que as pessoas com tais sintomas possam sofrer de transtornos psicológicos ou psiquiátricos e, por estarem em situação de fragilidade, tornam-se mais suscetíveis e mais facilmente sugestionáveis em tais reuniões, isto é, mais predispostas a manipulações psicológicas e experiências catárticas (CAMPOS, 1997, 349).

A guerra espiritual contra o diabo e seu séquito infernal ganha dimensão maior à medida que são vistos como os portadores de todas as mazelas sofridas pelo homem. Uma das principais funções desempenhadas pela IURD e que motivou, principalmente, o arregimento significativo de fiéis foi a sua configuração como espaço sagrado de cura.

O sofrimento do homem, segundo o Bispo Macedo, não se caracteriza como um desejo de Deus, sendo, desta forma, obra do diabo. O ser humano é por natureza, perfeito e feliz. As dores, enfermidades e a morte foram decorrentes da transgressão cometida por Adão e Eva, no entanto, a redenção foi alcançada por meio do sacrifício de Jesus. A IURD se propõe a libertar qualquer homem ou mulher que estejam padecendo os males da vida, a fim de que consigam encontrar consolo e conforto.

A possibilidade do fiel em reescrever sua vida se dá por meio do encontro com Deus, cuja ação está no sentido de re-instaurar a situação originária antes do pecado. Para que isso aconteça, Deus precisa se mostrar por enigmas, instando o fiel a traduzi-los (LAPLANCHE, 2003, p. 403-418). Os bispos e pastores, nesse contexto, enquadram-se como tradutores da mensagem divina, propiciando elementos a serem escritos na história do fiel. 
Religare, ISSN: 19826605, v.16, n.1, agosto de 2019, p.282-305.

A tradução desses enigmas divinos ao homem, que estão na bíblia, mas somente acessíveis através da interpretação feita pelos profetas de Deus da IURD, ocorre mediante a consolidação da Teologia da Prosperidade, a partir da qual o fiel assume uma postura de enfrentamento em relação a Deus. Tal postura se configura por uma exigência de tomar posse das bênçãos (confissão positiva/negativa), isto é, da cura para as mais diversas formas de sofrimento físico, mental, espiritual e econômico. Por meio da autoridade das palavras do pastor ou do bispo, da obediência do fiel e da expulsão do diabo, responsável pelo mal, o milagre acontece.

Desacreditados pelos médicos, sem condições de tratarem suas doenças ou vícios, muitas vezes por falta de recursos financeiros, oriundos de famílias desajustadas que não lhe conferiram um amparo devido para as suas necessidades mais básicas, desempregados, empresários falidos, casais que vivem o drama da separação ou da violência doméstica, certamente, encontrarão um espaço de elaboração de seus males em algum templo iurdiano, que lhes oferecerá um acolhimento tal como um pronto-socorro espiritual.

A Fogueira Santa do Monte Sinai, uma das correntes mais famosas da IURD, tem como objetivo provar que nada é impossível para Deus. Trata-se de mais uma estratégia original e bastante impactante, pois consiste em reunir os pedidos feitos em todas as igrejas universais do mundo e levá-los para serem queimados e apresentados a Deus no Monte Sinai em Israel, lugar sagrado de manifestação divina ao seu povo na antiguidade: “E assim como no passado Israel alcançou as suas grandes maravilhas, o mesmo tem ocorrido nos dias atuais na vida de todos os que crêem, por meio da Fogueira Santa."3

Essas associações com passagens bíblicas isoladas, geralmente do Antigo Testamento, são recorrentes na IURD. Configuram-se como recursos pedagógicos muito poderosos, uma vez que são facilmente apropriados tanto

\footnotetext{
3 Site da Universal. Disponível em: https://www.universal.org/noticias/o-que-e-a-fogueira-santado-monte-sinai. Acessado em: 04/05/2018.
} 
Religare, ISSN: 19826605, v.16, n.1, agosto de 2019, p.282-305.

pelos fieis como por quaisquer pessoas que estejam desesperadas em busca de uma benção imediata. No entanto, exige-se da pessoa que participa, enquanto a campanha durar, toda a sua fé e sacrifício, material e espiritual, para que ocorra o cumprimento das promessas Divinas em sua vida:

Assim como alguém se sacrifica para ser um profissional bemsucedido, quem almeja fazer a diferença em todas as áreas da vida também deve se sacrificar.

A Fogueira Santa do Monte Sinai é para as pessoas dispostas a fazer o verdadeiro sacrifício, entregando a Deus a vida por inteiro. É uma troca. Deus nos dá a Sua plenitude e nós O entregamos tudo o que somos. Em outras palavras, somos o próprio sacrifício.

Se você não aceita continuar vivendo da mesma forma que vive há anos, sem sinal algum de mudança, mas quer tomar uma atitude em relação ao momento em que está vivendo, requerendo as promessas que Deus nos faz em Sua Palavra, então a Fogueira Santa é para você.

Independentemente de sua religião ou credo, manifeste a fé no Único que é capaz de transformar a sua vida por inteiro. ${ }^{4}$

Estabelece-se a partir de então uma economia sacrificial ritualística, que se caracteriza como uma contribuição teológica original da IURD para a construção da Teologia da Prosperidade. Sua lógica de funcionamento está vinculada ao princípio da confissão positiva. O fiel precisa ter bem definido um objetivo que deseja alcançar (qualquer tipo de benção), depois deve estar disposto a testar sua fé em Deus por meio de sacrifícios materiais (ofertas e dízimos), sob um determinado ritual sagrado instituído pela Igreja.

Macedo esclarece como o fiel pode trilhar o caminho da oferta de sacrifício. Inicialmente, explica que o pecado abriu um abismo infinito entre o homem e Deus. Porém, Deus criou um caminho de mão dupla cujo objetivo era religar o homem a Ele.

Ainda de acordo com o Bispo, Deus ofereceu como oferta de sacrifício a vida de seu filho unigênito que morreu por nossos pecados. Cristo ao ser

\footnotetext{
${ }^{4}$ Idem.
} 
Religare, ISSN: 19826605, v.16, n.1, agosto de 2019, p.282-305.

crucificado assumiu nossas culpas, nossas iniquidades, nossas enfermidades e todas as desgraças que assolam o mundo. Ele concentrou em seu corpo todas as nossas maldições e ao ressuscitar criou uma ponte que liga a criatura ao seu Criador. Agora o homem precisaria trilhar esse caminho por conta própria, oferecendo também um sacrifício:

(...) A ponte foi feita através de seu filho Jesus. Agora essa ponte é de mão dupla. Tem o caminho feito pelo Senhor Jesus, agora tem que haver o caminho feito pelo homem. (...) Quando a gente fala em oferta, a oferta que você fisicamente traz no altar tipifica a oferta que Deus fez para salvá-lo que é Jesus. Jesus foi a oferta que Deus deu para nos salvar. (...) então Ele, como é tipificado pela oferta, representa a nossa defesa ou a nossa acusação. Você pode ler em Hebreus 11:4. Veja só o segredo da oferta. A extensão da oferta. Eu peço que você use sua razão, use sua inteligência, use o seu pensamento. Raciocine comigo: "Pela fé Abel ofereceu a Deus maior sacrifício do que Caim, pelo qual alcançou testemunho de que era justo." Quer dizer: a oferta de sacrifício de Abel testemunhou de Abel, falou por Abel diante de Deus: ele é justo. A oferta de Abel é quem o defendeu diante de Deus. É quem disse: olha Abel é justo. Então Deus aceitou a oferta de Abel. (...) Como é o caso do Altar. Quando você tem fé, você vem junto do altar e coloca a sua oferta. A sua oferta fala por você. A sua oferta da mesma forma que a oferta de Abel vai falar por você. Ela vai dizer se você é justo ou injusto. Se você é justo Deus aceita a sua oferta que é a sua vida. ${ }^{5}$

A oferta de Abel foi justa e Deus a aceitou, ao contrário de Caim cuja oferta serviu para testificar o seu pecado de inveja em relação ao irmão. A relação entre a justiça e o sacrifício é estabelecida por Macedo com a intenção de justificar a economia sacrificial. Deus para fazer valer a sua santa justiça e salvar o homem precisou entregar Jesus, o Cordeiro imaculado, como sacrifício pelos pecados da humanidade e, em contrapartida, o homem para ser visto como justo diante de Deus precisa sacrificar no altar da igreja aquilo que lhe é mais importante: a sua vida e o seu dinheiro.

\footnotetext{
${ }^{5}$ Canal do Bispo Macedo. Disponível em: https://www.youtube.com/watch?v=Nd1Mhi2zc2A. Acessado em: 02/05/2018.
} 
Religare, ISSN: 19826605, v.16, n.1, agosto de 2019, p.282-305.

Quando a campanha da Fogueira do Monte Sinai chega ao seu término, a IURD mostra os resultados por meio de diversos testemunhos: ${ }^{6}$

(bispo Rogério) Não existe uma área que o altar não resolva, o problema não seja solucionado no altar do sacrifício. (...) porque o altar do sacrifício coloca um ponto final na escravidão, na dor, no fracasso, no desespero e faz essa pessoa com certeza alcançar o sobrenatural. (...) Qual o nome do senhor? Eric. Mora onde? Ubatuba. Quem era o senhor antes do altar do sacrifício? Qual era a sua situação? Cheguei dando rasteira em cobra e chamando urubu de meu louro. Com extrema dificuldade. (...) eu era um projeto de homem. Eu não dava honra para a minha esposa, para a minha família. Era difícil. Não tinha nada? Nada morava na comunidade. Paga um aluguel de trezentos e oitenta reais. O que mudou no altar do sacrifício? Hoje eu sou um homem honrado. Hoje eu sou exemplo de homem para minha família, para os meus amigos. Tenho respeito. Sou um homem realizado. O Sr continua morando na favela? Não hoje eu moro numa casa de dois milhões de reais em um dos melhores condomínios de Ubatuba. Sou um empresário bem sucedido. (...) trabalho com uma linha de clientes de alto nível. Faço construção de casas de alto padrão. Tenho uma vida realizada em todas as áreas. Mais um resultado da fogueira santa! Mais uma pessoa que colocou um fim na escravidão e mudou de história! Não mudou apenas uma área. Mudou de vida.

O testemunho acima revela a interiorização pelos fieis da IURD da doutrina do sacrifício teologizada pelo Bispo Macedo. O Bispo Rogério afirma que qualquer problema é resolvido no altar do sacrifício. Não há nada que Deus não possa fazer quando o homem faz a sua parte nesse acordo. Eric chegou à IURD falido, um projeto de homem, sem honra alguma, desmoralizado diante de sua família e amigos. Morava de aluguel em uma comunidade, mas bastou fazer a corrente da Fogueira Santa, realizar o seu sacrifício material e espiritual, para que Deus lhe abençoasse quebrando as correntes da escravidão. Sua vida mudou, em todas as áreas, pois de empregado chegou à condição de empresário.

\footnotetext{
6 Site da Universal. Disponível em: https://www.youtube.com/watch?v=HnSyME7f7wc. Acessado em: 05/05/2018.
} 
Religare, ISSN: 19826605, v.16, n.1, agosto de 2019, p.282-305.

Interessante observar que o sacrifício por meio da oferta também está diretamente ligado ao exorcismo. Afinal se o diabo é o responsável por todas as mazelas que assolam o ser humano, somente uma prova de fé inabalável em Deus, dando tudo o que se tem, poderá suplantar o próprio Mal: “ao demônio se pergunta, então, se todos os que acabaram de participar do ofertório realmente deram tudo ou se alguém escondeu alguma coisa (ANTONIAZZI, 1994, p. 245)."

Os demônios, antes de serem expulsos dos corpos das pessoas, são intimados a falar seus nomes e revelar suas verdadeiras intenções em relação ao ser humano. Desmascarando-os na frente de um grande público, o discurso religioso iurdiano, alicerçado na Teologia da Prosperidade, ganha legitimidade e status de superioridade em relação à teodiceia afro-brasileira. O rito de exorcismo cumpre um papel fundamental na liturgia da IURD a partir da relação de similaridade estabelecida entre os orixás e os demônios que assolam a vida das pessoas (BONFATTI, 2000, p.86).

Desta forma, possessão e exorcismo, dois lados de uma mesma moeda, configuram-se como o pilar teológico da IURD caracterizado por uma verdadeira batalha espiritual. Essa cruzada cotidiana contra o diabo, tornando-o por certo protagonista nos cultos, tem a sua razão de ser devido à experiência do bispo Macedo com a Umbanda e o Espiritismo e de muitos fieis egressos de diversas religiões afro-brasileiras. Macedo afirma que não nutre ódio por pessoas que frequentam essas religiões, ao contrário as considera enganadas pelo diabo, espiritualmente cegas, sendo a função da IURD libertá-las:

Na nossa igreja, temos centenas de ex-pais-de-santo e ex-mãesde-santo, que foram enganados pelos espíritos malignos durante anos. Depois de assistirem a uma de nossas reuniões motivadas pelos programas de radio ou televisão, ou levados por alguma pessoa que já frequentam nossos cultos, se transformam em novas criaturas (MACEDO, 1997, p. 17). 
Religare, ISSN: 19826605, v.16, n.1, agosto de 2019, p.282-305.

A Catedral da Fé em Natal foi espaço da uma grande concentração de fé e milagres. O Duelo dos Deuses, realizado no dia 14/03/2013, reuniu milhares de pessoas e foi dirigido pelo especialista em paranormalidade, bispo Guaracy Santos:

A Caravana Duelo dos Deuses, realizada em diversos estados brasileiros, é uma concentração de fé cujo objetivo principal é promover a libertação de todos aqueles que são vítimas de problemas espirituais como bruxarias entre outros males. Todos que estavam doentes e se sentiam vítimas de algum mal foram chamados para frente do altar, onde o bispo determinou a cura e libertação. Centenas de milagres aconteceram após a oração da fé. Entre eles, estava Wagner, que durante cinco anos sofreu com um tumor que crescia dia após dia chegando a atingir o tamanho aproximado de uma laranja. Mas no momento da oração desapareceu, e o rapaz ficou curado. ${ }^{7}$

O Duelo dos Deuses é mais uma estratégia utilizada pela IURD com o objetivo de se legitimar frente às religiões de matriz afro-brasileira. Como o próprio título indica, trata-se de um desafio promovido pela igreja para libertar as pessoas que estão envolvidas com algum tipo de magia maligna. Nesse evento o foco é a cura física e a libertação espiritual. Muitas vezes os dois elementos estão diretamente relacionados, como foi o caso de Wagner que foi curado de um tumor instantaneamente após a oração ministrada pelo Bispo Guaracy.

O gênero feminino foi objeto específico de estudo do Bispo Macedo. Segundo o Bispo, a mulher que não está sob a graça e vontade de Deus está suscetível a se tornar servidora de Satanás. A história de Semíramis, rainha e que foi amante do próprio filho, pode ser considerada como principal exemplo desse caso.

Semíramis, segundo a sua visão, foi responsável por dar inicio a uma religião oculta desenvolvida pelo diabo, provavelmente, relacionada a um sistema religioso anterior ao Cristianismo, devido a suas ligações com o simbolismo da lua e a magia.

\footnotetext{
7 Site da Igreja Universal. Disponível em: https://www.universal.org/noticias/duelo-dos-deuses. Acessado em: 02/05/2018.
} 
Religare, ISSN: 19826605, v.16, n.1, agosto de 2019, p.282-305.

De acordo com a concepção da IURD, ela é assimilada á imagem da Virgem-Mãe pelos povos antigos, sendo que a partir dela surgiram outras mitologias congêneres, chegando a enganar até os católicos uma vez que sua representação se assemelha à imagem da Virgem Maria com o menino Jesus: "no Brasil, ela é Nossa Senhora Aparecida, a padroeira; em Portugal, a imagem tem o nome de Fátima e, no México, a Santa é a mesma, com o nome de Guadalupe (MACEDO, 2002, p. 27)."

A história de Semíramis é relatada no Blog do Bispo Edir Macedo:

Muitos cristãos, inocentemente, aderem a práticas religiosas sem ao menos se atentarem que, na realidade, repetem alguns dos mesmos atos e 'rituais' de culturas pagãs passadas. A comemoração do Natal e o 'culto' à sua árvore são exemplos de como muitos conseguem ser iludidos pela religião.

Para falar do NATAL, é preciso voltar ao tempo de NOÉ, após o dilúvio, quando um de seus filhos, CAM, o viu dormindo embriagado e nu. Ele começou a rir de seu pai e correu para contar aos seus outros dois irmãos, SEM e JAFÉ.

Estes, ao contrário, foram de costas e cobriram a nudez do pai. NOÉ, quando soube do acontecido, amaldiçoou seu filho CAM, para que este e seus descendentes servissem a seus outros dois filhos. E toda a geração após ele se tornou maldita.

CAM casou-se com SEMÍRAMIS (esta é a mulher da nota de 1, 2, 5, 10, 20, 50 e 100 reais; a mulher da Estátua da Liberdade; a mulher da balança da justiça; da Columbia Pictures, etc.) e ambos geraram um filho, NINRODE. Ele matou seu pai CAM e casou-se com sua mãe. Foi o fundador da Babilônia, Nínive e outras cidades pagãs. Tentou levantar a torre de BABEL, e DEUS o impediu.

Seu tio SEM o matou, pois ele estava se opondo muito contra DEUS. SEMÍRAMIS, sua mãe e esposa, espalhou a mentira de que ele não havia morrido, e sim que havia ido para o céu, pois ele se dizia deus - o deus sol.

SEMÍRAMIS engravidou e dizia ser um presente dos deuses, que era a reencarnação de NINRODE; mas, na verdade, era fruto de uma traição, pois seu marido, e filho, já estava morto. E nasceu TAMUZ, no dia 25 de dezembro, deus sol dos egípcios, babilônicos, gregos, persas, romanos e, hoje, das S.S. (sociedades secretas).

Ele morreu durante uma caça, provavelmente por um animal selvagem, e seu corpo ficou caído sobre um tronco apodrecido de árvore. Sua mãe dizia que neste tronco nasceu um pinheiro, 
Religare, ISSN: 19826605, v.16, n.1, agosto de 2019, p.282-305.

e todos os anos, no dia 25 de dezembro, era comum as pessoas levarem um pinheiro para dentro de casa e o enfeitarem com ouro e prata, como símbolo do renascimento de TAMUZ. ${ }^{8}$

A mulher que não vive sob a vontade de Deus servirá, tal como Semíramis, como instrumento do diabo para propagar todos os males por livre e espontânea vontade. Estigma que nos remete às representações de Eva, seduzida pela serpente, e da bruxa, serva de Satanás, perseguida pela Inquisição.

Da mesma forma, mulheres que vivem livremente sua sexualidade ou deixam transbordar sua sensualidade "o fazem porque têm um espírito demoníaco, chamado pomba-gira." ${ }^{9}$ No entanto, as mulheres honradas, piedosas e fieis a Deus são sábias e edificam o seu lar (Provérbios 14: 1), pois seguem fielmente no caminho que Deus lhes designou, isto é o caminho da virtude, trilhado por mulheres como Noemi e Rute:

Noemi saiu de Belém de Judá junto com o seu marido, Elimeleque, e seus dois filhos, Malom e Quiliom, por causa da fome. Chegaram ao campo de Moabe e ali morreu Elimeleque. Ela ficou com seus dois filhos, que depois se casaram com as moabitas Rute e Orfa. Depois de 10 anos, morreram também seus filhos, e Noemi ficou sozinha com suas noras (Rute 1.1-5). Porém, ouvindo Noemi que o Senhor tinha dado pão ao seu povo, levantou-se com suas noras e começou a caminhar para voltar a Judá. No meio do caminho, o silêncio entre as três foi quebrado com um pedido dela para que suas noras voltassem para seus povos (Rute 1.6-9).

Em um primeiro momento, ambas se negaram e disseram que continuariam com Noemi. Mas ela insistiu, argumentando que não tinha mais filhos que pudessem se casar com elas. Todas começaram a chorar. Orfa beijou sua sogra e voltou ao seu povo. Porém Rute se apegou a Noemi e nada a fez mudar de ideia (Rute 1.10-22). ${ }^{10}$

\footnotetext{
8 Blog do Bispo Edir Macedo. Disponível em: https://blogs.universal.org/bispomacedo/2013/01/21/semiramis-obelisco-e-a-farsa-do-natal/. Acessado em: 08/05/2018.

9 Idem. p. 38.

10 Site da Universal. Disponível em: https://www.universal.org/noticias/o-que-noemi-rute-eorfa-podem-ensinar-sobre-amizade. Acessado em: 07/05/2018.
} 
Religare, ISSN: 19826605, v.16, n.1, agosto de 2019, p.282-305.

Em uma entrevista com encosto no Brás, título de um vídeo postado no Canal do Bispo Macedo, pode-se perceber claramente a espetacularização das possessões nos cultos iurdianos. Uma mulher possuída fica ajoelhada e com as mãos para trás diante do auditório. O pastor faz uma entrevista com a entidade maligna: ${ }^{11}$

Qual o teu nome? (o pastor pergunta) Belzebu (responda a mulher). Ela foi obreira quanto tempo? Quase 10 anos. Qual foi a estratégia que você fez para tirar ela (sic)? Esfriamento, cansaço, não lia mais a palavra de Dele. Não lia mais? Não saía para evangelizar (dá risadas estrondosas). Que era o principal. Ai eu falei para ela: entrega teu uniforme. Fica de membro. Ai eu tive muita paciência, o que eu mais tenho é paciência para esperar (ri novamente). Foi muito fácil. Ela ia domingo. Dia de quarta não, já fui domingo! sexta-feira? De forma alguma. "se" era obreira (ri alto novamente). Até que eu quis ela para mim (sic). E ai eu brinco com ela, mas hoje eu não vou brincar mais não. você foi fazendo ela deixar de ler a bíblia? Lia num dia no outro já não precisava ler mais. (...) um dos meus cavalos estava lá, falando com ele. Se enforca, já era. Mas até na última chance. No último tempo Teu Senhor falou com ele. Lá na casa dele (pergunta o pastor)? Mandou Miguel falar com ele, mas ele não quis. E o teu Senhor até virou as costas pra não ver nós receber a alma dele (sic).

A cena é aterrorizante. A mulher fala com uma voz sufocante. Sussurrando ajoelhada responde todas as perguntas feitas pelo pastor. Trata-se de uma obreira da IURD que se desviou da fé por influência direta do diabo. Chama a atenção um relato da entidade sobre o suicídio de um homem que foi induzido por um dos seus cavalos, clara menção a um termo usado na Umbanda que serve para designar a incorporação de um Guia em um pupilo.

A intenção é muito clara, pois serve de alerta para todos os fieis não abandonarem a igreja. $\mathrm{O}$ diabo tem o poder de se apossar dos corpos até mesmo de cristãos desviados, uma vez que estão suscetíveis à influência do diabo.

11 Canal do Bispo Edir Macedo. Disponível em: https://www.youtube.com/watch?v=MyGBiFcKth0. Acessado em: 02/05/2018. 
Religare, ISSN: 19826605, v.16, n.1, agosto de 2019, p.282-305.

Macedo afirma que a pomba-gira maria molambo seria responsável também por diversos problemas de saúde que assolam as mulheres, como o câncer de útero e de ovários, e também pelos casos de homossexualismo (MACEDO, 1997, p. 25-47).

No caso do homossexualismo é possível ficar curado através do exorcismo. Para a IURD o homossexualismo é caso inequívoco de possessão demoníaca. Em um programa de rádio dirigido pelo Bispo Macedo, disponível me vídeo no Youtube, ocorre um caso de exorcismo deste tipo ${ }^{12}$ :

Então nós vamos ter agora o Bispo Clodomir fazendo um trabalho de libertação do Leandro. Você vai ficar liberto agora viu Leandro! Você crê? Sim senhor. Eu tenho certeza que você crê e é por causa dessa fé que nós vamos lhe ajudar.

Olha ai a razão da infelicidade dele, da família inteira (o rapaz coloca as mãos para trás, postura típica de quem está possuído). O principal, o cabeça, o chefe, o primeiro que entrou aí (o bispo Clodomir quer falar com o demônio líder da legião que incorporou no rapaz). Maldito! (afirma o demônio).

Agora Clodomir não se esqueça que a mãe, o pai, a família dele que estava na igreja foi tirada por essas entidades (Bispo Macedo). Trás? (pergunta o bispo Clodomir, fazendo referência a revelar todos os demônios que estão no rapaz). Ah um pacote! Faz um pacotão aí (Macedo). Diz a Érica, Bispo: bom dia Bispo, o programa está arrebentando e até me faz lembrar um consultório médico, mas esse é um espiritual (em meio ao exorcismo há mensagens lidas ao vivo de pessoas que acompanham o programa pelo rádio).

(...) Vamos lá (Clodomir). Todos os que estão aí! (o rapaz fica rodopiando com as mãos para trás e o bispo Clodomir com as mãos sobre a sua cabeça). (...)

Essa é a autoridade que nosso Deus nos deu! (o rapaz já está ajoelhado, com as mãos para trás, e o bispo Clodomir sentado em uma cadeira).

- Como você o levou a essa vida de homossexualismo (pergunta Clodomir)?

- Eu recebi um trabalho! (afirma o demônio)

- Recebeu um trabalho de quem? (Clodomir)

- De um vizinho dele. (demônio)

- Por que o vizinho fez esse trabalho, por qual razão? (Clodomir)

\footnotetext{
${ }^{12}$ Disponível em: https://www.youtube.com/watch?v=PN6AXJxJnSs. Acessado em: 07/05/2018.
} 
Religare, ISSN: 19826605, v.16, n.1, agosto de 2019, p.282-305.

- Ele desejava ele (demônio)

- Ah porque o vizinho desejou como homem então fez esse trabalho? (Clodomir)

- Fez! (demônio)

- Trabalho feito aonde? (Clodomir)

- Na encruzilhada maldito! (demônio)

- Que dia da semana esse trabalho foi feito? (Clodomir)

- Sexta-feira. (demônio)

- Quantas vezes, foi muitas vezes, ele te pagou muito, pouco, como é que foi? (Clodomir)

- Duas vezes (demônio)

- Então vem quem está no vizinho, vamos lá! (Clodomir)

- Agora é importante você entender minha amiga e meu amigo, que o Bispo Clodomir está chamando que está no vizinho, porque a origem da desgraça desse rapaz parece estar no vizinho. Então o diabo que está no vizinho vai vir aqui prá fazer a limpeza total! A gente vai na raiz!

Trata-se de uma legião de demônios que se apoderou do corpo do Leandro e o tornou afeminado em razão de um trabalho feito em uma encruzilhada por um vizinho que supostamente o desejava. Interessante observar que o trabalho de magia foi feito na sexta-feira, o mesmo dia da semana que a IURD reserva para a corrente da libertação. O homossexualismo é visto como um encosto, uma maldição que pode ser quebrada mediante a fé em Deus.

A IURD tem se destacado por ser uma igreja com um imenso potencial para se reinventar ao longo de sua história. Esse parece ser o caso do slogan Eu sou a Universal, ${ }^{13}$ uma estratégia de marketing com o intuito de mostrar tanto sua diversidade, quanto seu valor enquanto instituição religiosa. No site da igreja encontram-se diversas histórias e o objetivo é mostrar que há pessoas bem-sucedidas em todas as áreas profissionais. A chamada é a seguinte: O que é a Universal? Ou talvez seja melhor perguntar "quem é a Universal"?

\footnotetext{
${ }^{13}$ Disponível em: http://www.eusouauniversal.com/a-universal. Acessado em: 30/04/2018.
} 
Religare, ISSN: 19826605, v.16, n.1, agosto de 2019, p.282-305.

O testemunho de Claudio Soares, morador de rua, expulso de casa pela mãe aos oito anos de idade e preso na adolescência devido à prática de diversos delitos, revela uma vida que chegou ao fundo do poço:

Nasci negro, pobre, no lixo, largado, rejeitado... e eu pensei que a vida era assim, que eu ia viver e morrer assim. Você deve estar se perguntando quem sou eu hoje? Sou um empresário de sucesso, perito em trânsito, dou emprego a dezenas de famílias. Tenho esposa, sou patrão, sou amigo, um homem de sucesso. Eu sou um vencedor! Eu sou Cláudio Soares um ex-morador de rua que renasceu das cinzas. Quer saber a razão? Eu sou a Universal. ${ }^{14}$

Patrícia Leal tinha tudo para ter uma vida derrotada. Estava falida, sem emprego e separada de seu companheiro. Teve uma infância muito difícil, pois foi abusada por seu pai dos oito aos treze anos, até que decidiu dar um fim em toda essa dor. Hoje ela é casada novamente com o mesmo marido:

Em toda a minha história aprendi uma lição muito importante. Definitivamente, querer não é poder. Eu sempre quis ser feliz, mas não conseguia até que algo provocou a mudança da minha vida. Eu sou Patrícia Leal de vítima de pedofilia e mulher traumatizada, tornei-me uma empresária de sucesso, pronta par conquistar o mundo. Eu sou a Universal. ${ }^{15}$

Ana Paula Borgo, atleta da seleção brasileira de Vôlei, também se destacou em seu trabalho. Relata que as dificuldades e obstáculos nunca a impediram de realizar o seu sonho: “Eu sou Ana Paula Borgo. Sou uma mulher de personalidade. Uma guerreira, por isso eu nunca desisto dos meus sonhos. Eu sou jogadora de vôlei. Eu sou a Universal."16

A dupla sertaneja Thales e Vicente, que ganhou o prêmio de dupla revelação no Estado do Mato Grosso, conquistou o sucesso e o reconhecimento em seu trabalho com uma média de quinze shows por mês: "Somos do Mato

\footnotetext{
${ }^{14}$ Disponível em: https://www.youtube.com/watch?v=puk0aiWEAug. Acessado em: 20/05/2018.

${ }^{15}$ Disponível em: https://www.youtube.com/watch?v=1HjwS2v2ggg. Acessado em: 20/05/2018.

${ }^{16}$ Disponível em: https://www.youtube.com/watch?v=T1jJGfddRFw. Acessado em: 20/05/2018.
} 
Religare, ISSN: 19826605, v.16, n.1, agosto de 2019, p.282-305.

Grosso. A música faz parte de nossas vidas. Somos a dupla sertaneja Thales e Vicente. Nós somos a Universal."17

O peão de rodeio Edmilson Gonçalves é um homem determinado. Desde a infância desejava ser peão de boiadeiro e aos 17 anos começou a sua carreira de sucesso, sendo inclusive campeão de um importante torneio nos Estados Unidos da América: “hoje eu posso fazer a minha própria agenda e escolher os eventos onde montar. Eu sou Edmilson Gonçalves, sou competidor de montaria em touro. Vim do interior, mas já conquistei o Brasil na arena. Meu próximo passo é ser campeão mundial. Eu sou a Universal."18

Como se pode observar, as bênçãos são sempre benfazejas aos filhos $d a$ promessa que possuem uma compreensão mais aprimorada da natureza de Deus, cujas ações são determinadas pela fé e ousadia dos seus filhos. A IURD tem se constituído, ao longo de sua trajetória, como um espaço de religiosidade que combina, por meio da Teologia da Prosperidade, os recursos inerentes à racionalidade moderna com uma visão singular do sagrado.

A IURD se organiza como um empreendimento empresarial, com uma rede midiática extremamente complexa que exige uma elevada racionalidade administrativa. Seu segmento de mercado é bem definido uma vez que seu produto final é a operacionalização da benção sobre a vida dos fieis. Esse mercado de bens religiosos tem um enorme potencial de crescimento, justamente, por operar em seus fieis a internalização dessa ética neopentecostal de prosperidade.

Não deixa de configurar um paradoxo o fato de que a IURD opera com uma racionalidade moderna inerente a sua organização institucional que está a serviço de uma concepção do sagrado, absolutamente, distante da ideia weberiana de desencantamento do mundo.

\footnotetext{
${ }_{17}$ Disponível em: https://www.youtube.com/watch?v=7MwudosbZ5k. Acessado em: 20/05/2018.

${ }^{18}$ Disponível em: https://www.youtube.com/watch?v=Bu9fDxAmyw . Acessado em: 20/05/2018.
} 
Religare, ISSN: 19826605, v.16, n.1, agosto de 2019, p.282-305.

A resposta para essa aparente contradição pode ser encontrada na construção simbólica permanente produzida pelo ser humano. De acordo com Geertz, o homem, na tentativa de estabelecer uma compreensão do mundo que o cerca e de si mesmo, elabora distintos sistemas simbólicos que, no entanto, estão expostos às constantes transformações sociais inerentes à própria dinâmica da vida (GEERTZ, 1989, p. 101-142).

Na medida em que os diversos recursos disponíveis por esses sistemas simbólicos começam a se desarticular e produzir uma sensação de incerteza e caos, fragmentando tanto os mundos interno quanto o externo, muitos indivíduos recorrerão à religião como, possivelmente, o último recurso, que será evocada para dar conta e sentido à vida em sua totalidade.

O homem na tentativa de ordenar a sua vida diante da possibilidade de sucumbir em um mundo que lhe pareça desalinhado, acaba experimentando a mais profunda e obscura ansiedade, aquela que se configura como a mais insuportável de todas, a do incompreensível. Afinal como afirma Geertz: “a importância do significado na vida é o fim principal e a condição básica da existência humana (GEERTZ, 1989, p. 301)." É nesse contexto que a religião pode se tornar necessária.

O mundo da pós-modernidade produz nas sociedades ocidentais uma fina camada de racionalidade que obscureceu e até mesmo esconde a força simbólica das representações religiosas. Quando essa camada é retirada em razão das transformações socioeconômicas, ocorre um potente extravasamento dos símbolos antiquíssimos que traz a reboque toda a carga de significações soterradas.

Mesmo diante de toda força da secularização provocada pela ciência e pela modernidade, em tempos de angústia mais profunda, o homem ainda recorre à reserva inesgotável de simbolismos produzidos pelas experiências religiosas ao longo da história humana. 
Religare, ISSN: 19826605, v.16, n.1, agosto de 2019, p.282-305.

Mesmo em sociedades laicas, ou em processo de laicização, a religião, enquanto sistema simbólico produtor de sentidos, continuará a ter um inestimável papel de consolo para o homem, uma vez que talvez somente ela tenha condições de trazer significado à existência do bem e do mal, da morte e da vida, da saúde e do infortúnio que acompanham o ser humano em sua efêmera existência. Nesse sentido, a religião oferece ao indivíduo uma forma abrangente, totalizante de percepção do mundo.

O homem contemporâneo vive essa angústia existencial de forma mais viva e intensa, fruto da perda de sentido que resulta da acelerada transformação pela qual passa a sociedade. É provável que em tempos hodiernos, a reflexão de Marshall Berman sobre a modernidade, no prefácio de sua mais celebrada obra, ganhe ainda maior relevância:

Logo depois de terminado este livro, meu filho bem-amado, Marc, de cinco anos, foi tirado de mim. A ele eu dedico Tudo o que é sólido desmancha no ar. Sua vida e sua morte trazem muitas das ideias e temas do livro para bem perto: no mundo moderno, aqueles que são mais felizes na tranquilidade doméstica, como ele era, talvez sejam os mais vulneráveis aos demônios que assediam esse mundo; a rotina diária dos parques e bicicletas, das compras, do comer e limpar-se, dos abraços e beijos costumeiros, talvez não seja apenas infinitamente bela e festiva, mas também infinitamente frágil e precária; manter essa vida exige talvez esforços desesperados e heroicos, e às vezes perdemos (BERMAN, 1986, p.8).

Seria acertado afirmar que a IURD demonstrou rara capacidade de construir uma narrativa discursiva que, por meio da Teologia da Prosperidade, mantivesse, simultaneamente, a dimensão de contemporaneidade, típica de uma racionalidade moderna, e um espaço destinado ao sagrado, no qual essas novas significações foram rearticuladas, ensejando forte e irresistível atração para atrair adeptos.

O discurso da IURD tem a capacidade de sacralizar as demandas de uma sociedade que se percebe como secularizada e racional, mergulhada em um 
Religare, ISSN: 19826605, v.16, n.1, agosto de 2019, p.282-305.

profundo processo de modernização. A simbiose entre o laico e o sagrado, responsável pelas severas críticas e por todo mal-estar gerado em indivíduos e igrejas protestantes tradicionais, que não lançam mão da narrativa neopentecostal para produzir significações em suas vidas, tem sido a marca distintiva de sucesso da Igreja do Bispo Macedo, como atesta o seu vertiginoso crescimento.

Tal simbiose foi possível pela instrumentalidade da linguagem que pode ser compreendida como o caminho para se superar uma compreensão reducionista em relação à razão, vista somente em seu aspecto instrumental. Habermas, pensador da Escola de Frankfurt, acreditava que a linguagem seria o melhor canal para a revelação da razão:

\begin{abstract}
Há, portanto, além das razões estritamente metodológicas, um segundo - mas nem por isso menos importante - motivo para que seja a linguagem, e não o conhecimento ou a ação, o melhor medium através do qual a razão se revela: somente através da linguagem podemos ter acesso a uma forma de razão nãoinstrumental e não-subjetiva, isto é, a uma razão "comunicativa", essencialmente intersubjetiva, cujo único critério é promover o acordo racional entre os sujeitos, o que exclui, imediatamente, o uso de qualquer forma de coerção, externa ou interna (ARAGÃO, 1997, p.32-33).
\end{abstract}

Para Habermas a razão possui uma tripla dimensão: instrumental, normativa e expressiva. De forma similar à teoria tridimensional da razão, a teoria da evolução social de Habermas também pode ser compreendida como uma aplicação de sua teoria da racionalidade (ARAGÃO, 1997, p. 73). Desta forma, a sociedade em sua evolução se desenvolve em seus aspectos normativo, instrumental e relacional ou comunicacional:

Habermas crê que o motivo mais forte que levou homens a buscarem a convivência social e a evoluir enquanto espécie não foi o trabalho e sim a interação, e isto fica bastante claro, quando ele estabelece a aquisição da linguagem como o marco 
Religare, ISSN: 19826605, v.16, n.1, agosto de 2019, p.282-305.

decisivo para o início da história humana (ARAGÃO, 1997, p. 74).

A razão comunicativa, essencialmente intersubjetiva, tem a capacidade de articular as pessoas em torno de um objetivo primaz: a convivência social. A IURD se configura como um espaço de interação social por meio do qual ocorre a construção de sua própria identidade enquanto comunidade religiosa. $\mathrm{O}$ discurso iurdiano não só consegue atender as questões existenciais insolúveis, inerentes ao campo religioso por excelência, como também tem sido capaz de produzir distintas significações e soluções para outras áreas da vida, que não são necessariamente ligadas à religião.

A economia sacrificial reproduziu, por meio ritualístico, o grande amor de Deus pelo homem ao entregar seu filho unigênito em holocausto por nossos pecados. Sua morte de cruz teve a função de religar a criatura ao seu Criador. Caberia ao homem seguir o exemplo de Abel, que ofereceu o melhor que tinha, isto é, as suas primícias, e retribuir, com sua vida e ofertas, a graça divina que lhe alcançou.

Essa lógica de retribuição possibilitou o aprisionamento do sagrado à vontade soberana do homem. Deus, fiel a sua palavra, ficou obrigado a abençoar todo aquele que colocasse sua fé em prova. A IURD descobriu a chave com a qual abriria as portas do céu subvertendo, irremediavelmente, os papeis conferidos ao divino e ao humano.

A capacidade de harmonizar o secular com o sagrado proporcionou a modernização do discurso religioso, tornando-o mais eficaz e sedutor. A lógica do Toma-lá-dá-cá se constituiu como um forte apelo em relação tanto aos desamparados e oprimidos, vítimas de múltiplas exclusões socioeconômicas, quanto aos que buscam aumentar seu potencial econômico e empresarial. Nesse sentido, a IURD foi inexcedível, pois teve a coragem de assumir uma postura que contrariava a posição mais ortodoxa das igrejas protestantes históricas e pentecostais. 
Religare, ISSN: 19826605, v.16, n.1, agosto de 2019, p.282-305.

A Teologia da Prosperidade, sustentada pelas práticas e representações realizadas em relação ao diabo, viabiliza a consolidação, simultaneamente, do poder das lideranças neopentecostais na medida em que constroi uma áurea de sacralidade em torno de seus discursos, e da demonização das práticas religiosas ligadas ao espiritismo e às religiões afro-brasileiras.

O diabo foi alçado à condição de protagonista sem o qual dificilmente a IURD teria alcançado o destaque que tem hoje. Nesse sentido, cumpriu um papel fundamental de ser o adversário de Deus, conforme nos informa um julgamento de feitiçaria inglesa no último ano do século XVI onde se dizia que “sem diabo não há Deus. (THOMAS, 1980, p. 469)."

Suas diversas representações ensejaram inúmeras práticas ritualísticas e serviram para dar liga à Teologia da Prosperidade cuja lógica tem colocado o diabo a serviço de Deus e este a serviço do homem.

\section{Referências}

ALMEIDA, Ronaldo. Dissertação de mestrado em Antropologia Social. São Paulo, Unicamp, 1996.

ANTONIAZZI, Alberto. Nem anjos nem demônios: interpretações sociológicas do pentecostalismo. Petrópolis. RJ. Vozes, 1994.

ARAGÃO, L. M. C. Razão comunicativa e teoria social crítica em Jürgen Habermas. Rio de Janeiro: Tempo Brasileiro, 1997.

BERMAN, Marshall. Tudo o que é sólido desmancha no ar. Editora Schwarcz. São Paulo. 1986. Disponível em: http://www.oratoriaavancada.com.br/ebooks/ebook2.pdf. Acessado em: 20/05/2018.

BONFATTI, P. A expressão popular do sagrado: uma análise psico-antropológica da Igreja Universal do Reino de Deus. São Paulo: Paulinas, 2000.

BOURDIEU, P. A economia das trocas simbólicas. Rio de Janeiro: Bertrand, 1998.

CAMPOS, Leonildo Silveira. Teatro, Templo e Mercado: organização e marketing de um empreendimento neopentecostal. Petrópolis : Editora Vozes ; São Paulo : Simpósio Editora ; São Bernardo do Campo: UMESP, 1997. p. 349.

CASCUDO, C. Dicionário do folclore brasileiro. São Paulo: Ediouro, s.d. p. 353

GEERTZ, Clifford. A interpretação das culturas. Rio de janeiro. Zahar. 1989.

LAPLANCHE, Jean. Três acepções da palavra "inconsciente" no quadro da 
Religare, ISSN: 19826605, v.16, n.1, agosto de 2019, p.282-305.

Teoria da Sedução Generalizada. Revista de Psicanálise da Sociedade Psicanalítica de Porto Alegre, 10(3). 2003.

MACEDO, Edir. O Perfil da Mulher de Deus. Rio de Janeiro, Editora Gráfica Universal, 2002.

Orixás, caboclos e guias: deuses ou demônios? Rio de Janeiro:

Universal, 1997.

MARIANO, R. Neopentecostais: sociologia do novo pentecostalismo brasileiro. São Paulo: Loyola, 1999.

NOGUEIRA, C. R. F. O diabo no imaginário cristão. Bauru: Edusc, 2000.

PRANDI, Reginaldo. Mitologia dos orixás. São Paulo, Companhia das Letras, 2001.

Por que Exu é o primeiro? Texto extraído e modificado do livro Segredos Guardados, de Reginaldo Prandi, Companhia das Letras, 2005. http://www.espiritualidades.com.br/Artigos/P_autores/PRANDI_Reginaldo_tit_ exu_prim.htm

THOMAS, Keith. Religion and the decline of magic - studies in popular beliefs in XVIth century England. 4. ed. Londres, Widenfeld and Nicolson, 1980.

Recebido em 30/07/2018.

Aprovado em 26/07/2019. 